\title{
ПРОИЗВОДНЫЕ (1R, 2R, 6S)-3-МЕТИЛ-6-(ПРОП-1-ЕН-2-ИЛ) ЦИКЛОГЕКС-3-ЕН-1,2-ДИОЛА В КАЧЕСТВЕ ПЕРСПЕКТИВНЫХ ВЕЩЕСТВ С ПРОТИВОПАРКИНСОНИЧЕСКОЙ АКТИВНОСТЬЮ
}

\author{
А.В. Подтуркина, О.В. Ардашов, А.В. Павлова, Т.Г. Толстикова, \\ К.П. Волчо, Н.Ф. Салахутдинов \\ Федеральное государственное бюджетное учреждение науки \\ Новосибирский институт органической химии им. Н.Н. Ворожцова \\ Сибирского отделения Российской академии наук, \\ 630090, Российская Федерация, г. Новосибирск, пр. Академика Лаврентьева, д. 9.
}

DOI: 10.19163/MedChemRussia2021-2021-302

E-mail: podturkinaa14@gmail.com

Болезнь Паркинсона является возрастным нейродегеративным заболеванием, которое характеризуется прогрессирующим ухудшением двигательной системы. У пациентов с болезнью Паркинсона проявляются такие симптомы как тремор, брадикинезия, ригидность и постулярная неустойчивость. Лекарственное средство леводопа, которое является основным препаратом для купирования симптомов болезни Паркинсона, имеет серьезные побочные эффекты [1]. Поэтому разработка новых лекарств для эффективного лечения этой болезни является актуальной задачей.

Ранее в Новосибирском институте органической химии было найдено, что монотерпеноид (1R, 2R, 6S)-3-метил-6-(проп-1-ен-2-ил)циклогекс-3-ен-1,2-

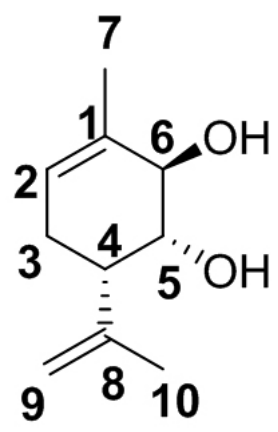

диол (1) проявляет высокую противопаркинсоническую активность [2], агент находится на первой стадии клинических испытаний. Были получены S- $N$ - и C-производные соединения (1), модифицированные по аллильному положению 10, некоторые из них проявили хорошую противопаркинсоническую активность, особенно вещества с пропилтио и бутильным заместителями [3].

В данной работе проведены различные модификаций соединения (1) по аллильным положениям 6 или 10 , или одновременно по 6-му и 10-му положениям с введением различных заместителей, в том числе изучена их противопаркинсоническая активность.

Авторы благодарны РФФИ за финансовую поддержку (грант N 19-03-00071).

\section{Литература}

[1] A.K. Kakkar et al. Eur. J. Pharmacol., 2015, 750, 74-81.

[2] O.V. Ardashov et al. J. Med. Chem., 2011, 54, 3866-3874.

[3] O.V. Ardashov et al. Bioorg. Med. Chem., 2013, 21, 1082-1087. 